\title{
Gazette
}

\section{APSA Awards Presented at 1991 Annual Meeting}

\section{DISSERTATION AWARDS}

\section{Gabriel A. Almond Award (\$250)}

For the best doctoral dissertation completed and accepted during 1989 or 1990 in the field of comparative politics.

Award Committee: Sidney Tarrow, Cornell University, chair; Rodolfo O. de la Garza, University of Texas; Cynthia $\mathrm{H}$. Enloe, Clark University.

Recipient: Michael Barnett, University of Wisconsin, Madison.

Dissertation: "War Preparation and the Restructuring of State-Society Relations: Israel and Egypt in Comparative Perspective," submitted by the University of Minnesota.

\section{Dissertation Chair: Raymond Duvall.}

Citation: This monumental piece of work, written at the University of Minnesota, presents a theoretical framework for examining the relations between war preparation, mobilization and state power and applies it in a systematic paired comparison of Egypt and Israel from about 1950 until 1977. As well as demonstrating the comparative method at its best, Barnett's work shows that there is no contradiction between good theory and careful empirical study, and demonstrates once again-if it needed demonstration-that international relations do not end at the water's edge. On the contrary, he shows convincingly that war preparation and its effects are dependent on the pre-war preparation social structure, and on the decisions made by government officials. Barnett's findings will not only shed important light on significant similarities and differences between these two former enemies, but also relate in important ways to the problem of how states prepare for war and with what effects on their societies.

\section{William Anderson Award (\$250)}

For the best doctoral dissertation completed and accepted during 1989 or 1990 in the field of intergovernmental relations.

Award Committee: Jeanie R. Stanley, University of Texas at Tyler, chair; William Nelson, Ohio State University;
Richard L. Wilson, University of Tennessee at Chattanooga.

Recipient: Michael B. Berkman, Pennsylvania State University.

Dissertation: "The State Roots of National Politics: Regional Economic Disparities and the Congressional Tax Agenda, 1978-1986," submitted by Indiana University.

\section{Dissertation Chair: Edward G. Carmines}

Citation: Michael Berkman's dissertation clearly addresses a question in the mainsteams of state and local politics, federalism, and intergovernmental relations. Well written and conceived, this dissertation makes a valuable contribution to each of the subfields recognized by the Anderson Award.

Berkman uses a case study of federal tax policy to explore a model of congressional agenda change that incorporates the role of subnational politics in shaping the national agenda. Beginning with the Congress's rewriting of President Carter's 1978 tax reform proposal, he contends that American tax politics has been dominated by an agenda committed to cutting taxes to stimulate economic growth, an agenda that downplays traditional commitments to maintaining a progressive rate structure.

A simple proposition, explored in several ways, directs this research: national policymakers, in particular members of Congress, are products of their state political systems and environment. They bring to national politics ideas and approaches to government experienced in these state environments, ideas and approaches that are the products of their state's political culture and economic conditions. As the economy transforms through industrialization into a period characterized by uneven growth across states, state political and economic environments also change, effecting eventually the agenda at the national level.

Berkman's research traces the effects of regional economic disparities through the political system, focusing on their impact on the party system and the parties' sectional alignment. As the center of gravity for each party moves to sectional poles its agenda changes. For Republicans, the greater influence of the Sunbelt lead to a more conservative agenda; for Democrats, the socializing effects of state governments in the Rustbelt committed to tax cutting as a tool of economic development lead to important differences between the agenda promoted by junior and senior House members. These differences are uncovered through roll call analysis on tax bills in 1978, 1981, and 1986.

Different types of data are used to show the sectionalization of the parties, their changing ideological profiles, state political responses to changing economic conditions, and patterns of Congressional roll call voting. This dissertation is well written and conceived.

\section{Edward S. Corwin Award (\$250)}

For the best doctoral dissertation completed and accepted during 1989 or 1990 in the field of public law.

Award Committee: Doris Marie Provine, Syracuse University, chair; Dean Alfange, University of Massachusetts; Abraham L. Davis, Morehouse College.

Recipient: Terri Jennings Peretti, Santa Clara University.

Dissertation: "The Responsible Exercise of Judicial Power: In Defense of a Political Court" submitted by University of California, Berkeley.

Dissertation Chair: Nelson W. Polsby.

Citation: Dr. Peretti wrote her thesis at the University of California at Berkeley with Nelson Polsby, Robert Kagen, and Martin Shapiro serving on her committee. The thesis is a model of clarity and hardhitting argument. Her subject is contemporary constitutional theory, which she sees as a field in the grip of a misguided conception of the judge's role. Too many constitutional theorists, she argues, seek to write politics out of constitutional decision-making, or believe that would be desirable if only it were possible. She criticizes this approach and offers a reading of the constitutional plan that envisions judges who are politically astute in the exercise of their power.

Peretti suggests that the founders intended to make each branch of government permeable to the claims and complaints of citizens, including the Supreme Court. Theirs was a theory of government that we call pluralism, and access was a guiding concern. It follows that judges who acknowledge and act upon their power to disagree with the other branches are more loyal to the intention of the founding fathers than 
those who avoid such confrontations. They participate in a dialogue that helps guide the nation toward more intelligent decisions. Those who claim that the Court preserves its legitimacy with the democracy-minded American public by staying outside the fray misconceive the impact of the Court's intervention. Ordinary Americans are barely aware of the Supreme Court's existence, not to mention its substantive work, and in any event, the Supreme Court rarely has the last word on public-policy issues of pressing concern. Judicial process scholars in political science have made all this quite clear, but the academics who turn out prescriptions for judicial restraint, many of whom teach in law schools, tend to ignore social science. It's time for those constitutional theorists who abhor politics, especially judicial politics, to read the empirical literature on the Supreme Court and to rethink their knee-jerk aversion to a politicallyminded judiciary.

Our committee was impressed with the high intellectual quality and wide range of topics represented in the submissions this year.

\section{Harold D. Lasswell Award (\$250)}

For the best doctoral dissertation completed and accepted during 1989 or 1990 in the field of policy studies (supported by the Policy Studies Organization).

Award Committee: Bruce Smith, Brookings Institution, chair; Elizabeth Sanders, New School for Social Research; Norman C. Thomas, University of Cincinnati.

Recipient: Christopher McGrory Klyza, Middlebury College.

Dissertation: "Patterns in Public Lands Policy: The Consequences of Ideas and the State."

\section{Dissertation Chair: Virginia Gray.}

Citation: Christopher McGrory Klyza's Patterns of Public Lands Management is a superior study that links public policy with history and political theory. Cast in this appropriately broad framework, the dissertation shows how three distinct patterns of policymaking evolved in the management of the nation's public lands. Grazing, mineral rights, and forestry policy emerged as separate policy systems because of historical factors, the influence of ideas on political behavior, and the institutional interests of their parent bureaus. The result has been a complex and overlapping system of competing values held in uneasy equilibrium. This microcosm of the larger political system is analyzed with clarity and profound knowledge of the policy subsystem and a sure grasp of the broader theoretical implications. Dr. Klyza's study is noteworthy for the careful way in which he links his empirical findings with the literature of public policy. The dissertation is written with clarity and grace and is a worthy addition to the Harold D. Lasswell award winners.

\section{Helen Dwight Reid Award (\$500)}

For the best doctoral dissertation completed and accepted during 1989 or 1990 in the field of international relations, law, and politics (supported by the Helen Dwight Reid Foundation).

Award Committee: Matthew Evangelista, University of Michigan, chair; Catherine Kelleher, Brookings Institution; John Wilson Lewis, Stanford University.

Recipient: Debora L. Spar, Harvard University.

Dissertation: "Iron Hands: The Internal Sources of International Cooperation," submitted by Harvard University.

\section{Dissertation Chair: Stanley Hoffmann.}

Citation: This year saw the highest number of submissions ever, with many excellent dissertations, representing the full range of methods and subject areas in the study of international relations. Our choice as recipient of the 1991 Helen Dwight Reid Award is Debora L. Spar for her study of the sources of cooperation in international raw-materials commodity cartels. Spar's dissertation addresses one of the key questions in international-relation theory: "How, in a world of self-interested states, can cooperation ever triumph over anarchy?" Many students of international politics have attempted to answer this question by focusing on the structure of the international system. In its best known variants, structural theories of international politics draw on economic theories of the influence of market structure on firms' behavior. Spar finds such structural theories insufficient to account for cooperation in the market or in the international system.

The economic analogy for international cooperation is the formation of a cartel in an oligopolistic market. Yet, as Spar points out, in her review of the economic literature on oligopoly, structural theories have failed to identify the sufficient conditions for successful cartelization. Cartels have failed to form or preserve even in the presence of the five main structural conditions considered conducive to their formation: high concentration, small fringe (number of outside producers too small to be members of the cartel), high barriers to entry, non-substitutability and non-differentiation. Moreover, some raw-materials cartels (notably oil and bauxite) have succeeded, at least temporarily, in the absence of the structural attributes.

Structural theories of international politics-represented most notably by the theory of hegemonic stability-provide neither necessary nor sufficient conditions for the emergence of international cooperation. From this point of departure, Spar sets out to develop hypotheses about the internal characteristics of units-states or firms-which allow them to cooperate: "Since many of the most persuasive theories of international cooperation come directly from economic theories and are based in the economic logic of the cartel, it seemed to make sense to attack the question at its source-that is, to use an empirical study of cartels in order to explore the limits of a structural approach and to generate some new hypotheses about the internal sources of international cooperation."

Spar chooses her cases for variation on the dependent variable-the degree of successful formation of a cartel in an oligopolistic market. The markets she studies-diamonds, gold, uranium, and silver-all have the structural attributes considered conducive to cartelization, yet only the first two have successful cartels. Drawing on game theory and theories of institutions, Spar develops hypotheses that explain the relative degree of cooperation on the basis of the internal characteristics of the units. She agrees with game theorists on the central importance, for maintaining cooperation, of commitment, credibility, and retaliation. Yet, she argues, without relaxing the assumption of a unitary, rational actor, one cannot know which kinds of actors will be most capable of making credible promises and threats and of implementing them. Spar finds that international institutions can help manage producers' cartels, but that many of the characteristics that institutional scholars have identified as important-including formal rules, openness, and transparency-may actually be counterproductive to certain types of cooperation.

The internal variables that Spar associates with cooperation are the power of the actor, the shadow of the actor and the pockets of the actor. Power in this sense refers to the ability of producers or states to impose decisions and costs on internal factions, thereby enhancing their credibility and responsiveness vis-a-vis other actors. The shadow of the actor refers to the time horizon of the individual decisionmakers who participate in an international agreement; this usage contrasts with the more common gametheoretic concept which focuses on the anticipated number of iterations of the game. The pockets of the actor refers to the ability to suffer short-term losses associated with restraint in order to 
benefit from longer-term gains of cooperation. In Spar's cases the actors most capable of cooperating in the formation and maintenance of cartels are the Soviet Union and South Africa, whereas the United States and Canada are relatively unsuccessful. Her somewhat unsettling conclusion is that secretive, authoritarian states have more of the attributes necessary for international cooperation than do open, democratic ones. The conclusion runs counter to the popular notion that countries which trust their citizens make the most trustworthy international partners, and it poses important questions for future research: Is cooperation in other issue-areas-security policy, for example-associated with the same internal attributes as formation of commodities cartels? Given the apparent trade-off between international cooperation and domestic political freedom, what mechanisms or institutions might serve to make the two more compatible? In challenging the unitary-actor assumption and presenting a set of compelling hypotheses on the internal sources of international cooperation, Debora Spar has made an important contribution to the study of international relations and opened the way for further comparative studies in other issue-areas.

\section{E. E. Schattschneider Award (\$250)}

For the best doctoral dissertation completed and accepted during 1989 or 1990 in the field of American government.

Award Committee: Karen Orren, University of California, Los Angeles, chair; Michael Goldfield, Cornell University; Jerry G. Watts, Trinity College (CT).

\section{Recipient: Christopher Peter Gilbert,} Washington University.

Dissertation: "Religious Environments and Political Actors" submitted by Washington University.

Dissertation Chair: John Sprague.

Citation: Gilbert builds on the work of scholars over the last decade who have attempted to empirically demonstrate the social dimension of individual political behavior by operationalizing the concept of context. Using a variety of data and modeling strategies, he draws a series of concentric circles-county, church, and discussion partners-surrounding individual actors. The distribution of religious membership, church denomination and attendance, and participation in discussion with fellow church members are considered for their effect on actors' voting turnout and partisanship, attitudes on a diversity of policy issues, and individual self-evaluations.

The dissertation proceeds upon a theory in which contextual effects are transmitted through the reinforcement of individual views in discussion, with dissonance resolved by informationseeking. Throughout, Gilbert is sensitive to the existence of other contexts in which such reinforcement may occur and negate or subsume the influence of the context of church. One of the most intriguing aspects of the study is a finding that one perception of his or her religious group's majority or minority status affects the salience of church as opposed to other social cues, and the differential responses by Catholics and Protestants to each of these circumstances. Gilbert suggests that the ability to scan the environment for information as to relative religious strengths implies a more sophisticated citizen than portrayed in most studies of public opinion.

The argument is clearly reasoned and layed out. At every point the author relates his empirical findings to the mechanism of reinforcement theorized to produce them. The findings themselves are treated with due reserve, strengthening the author's case both for the importance of religious affiliations and institutions in politics and for the significance of social variables in the analysis of political behavior.

\section{Leo Strauss Award (\$250)}

For the best doctoral dissertation completed and accepted during 1989 or 1990 in the field of political philosophy.

A ward Committee: Nancy S. Love, Pennsylvania State University, chair; James S. Fishkin, University of Texas at Austin; Hanna Pitkin, University of California, Berkeley.

Recipient: Mark Lilla, New York University.

Dissertation: "A Preface to Vico: Skepticism, Politics and Theodicy," submitted by Harvard University.

Dissertation Chair: Judith N. Shklar.

Citation: Giambattista Vico was "a man living in the twilight of the 17th century, and not the dawn of the 19th (xv)." So argues Mark Lilla in his strikingly original Preface to Vico: Skepticism, Politics, Theodicy. Contrary to standard interpretations of Vico's New Science which present it as the "first modern science of history," Lilla portrays Vico as an at best "dissident modern" who sought a "compromise between the realistic modern outlook and a yearning for the consolation of theodicy (xxv)." It was to combat modern epistemological (Descartes and Leibniz) and political (Machiavelli, Hobbes, Spinoza, Bayle, and Locke) skepticism that Vico developed a "rational civil theology of divine providence" $-\mathbf{a}$ science constructed to reveal the Glory of God.

Lilla's reinterpretation of Vico reflects learned and meticulous scholarship. He considers the New Science in the larger context of Vico's early, often untranslated metaphysical and jurisprudential works, especially Universal Right. The result is a comprehensive treatment of Vico's entire philosophical opere. Yet Lilla also ranges far beyond Vico's texts and time to shed further light on contemporary historicist struggles. Vico's paradoxes, Lilla suggests, remain our own. Lilla neither attempts nor claims to resolve those paradoxes (though his work should assist others in that task). In this and other aspects, Lilla's style of interpretation and manner of argument are unusually judicious, even modest. His combination of restraint and insight is among the most admirable features of the dissertation. Lilla also writes with a degree of lucidity, economy, and grace that ought to make this work publishable as it stands. When published, it will provide not only a preface to Vico, but also a less anachronistic and more subtle view of the relationship between Christian theodicy and modern historicism.

\section{Leonard D. White Award (\$250)}

For the best doctoral dissertation completed and accepted during 1989 or 1990 in the field of public administration.

Award Committee: David H. Rosenbloom, American University, chair; Candace Hetzner, Boston, MA; Roger Marz, Oakland University.

Recipient: Alan Abramson, Urban Institute.

Dissertation: "Responsive Budgeting: The Accommodation of Federal Budgeting to Different Programs and Spending Regimes," submitted by Yale University.

Dissertation Chair: David Mayhew.

Citation: To paraphrase G. K. Chesterton, budgeting has not been tried and found difficult, but found difficult and so not been tried. Alan Abramson provides us with a clear paradigm that explains why the process is so difficult and why the difficulties that face wouldbe budgeters vary depending on the policy domains with which they are concerned.

There are, in his theory, four distinct budget processes: one for discretionary nondefense programs, one for defense, one for entitlements, and one for the often ignored credit programs of the national government. Within each of these domains the purposes and therefore the tactics of the actors vary depending on whether the funds available for programs are expanding or contracting. 
Abramson's approach does more than simply provide a better organized way to think about and describe budgetary processes. He also suggests relatively moderate reforms in each of the processes that could be adopted and which unlike the "balanced budget amendment," an approach which has little effect in those states which have it, might well make federal budgetary processes more rational. Budgeting will always be painful, but it need not be or seem to be anarchic. Thanks to Abramson's clear thinking and exhaustive historical research the federal budgeting is once more comprehensible.

Nothing is so practical as a good theory, and what makes a theory good is its utility in explaining events beyond those on which it is based. By recognizing the importance of credit guarantees as an encumbrance of the public fisc and enfolding them into his theory Abramson has given us a timely instrument with which to understand and therefore cope with what is likely to be the crucial budgetary problem of the nineties. Those who want to build on his work might wish to apply his theoretical approach to understanding the use of tax exemptions and abatements at the level of state and local governments. It seems likely that these too could be encompassed within his approach.

The Leonard White award is only as significant as the works it honors. This dissertation adds greatly to the award's luster.

\section{PAPER AND ARTICLE AWARDS}

\section{Franklin L. Burdette Pi Sigma Alpha Award}

For the best paper presented at the 1990 Annual Meeting (supported by Pi Sigma Alpha).

Award Committee: Aristide R. Zolberg, New School for Social Research, chair; Liane C. Kosaki, Washington University; David Vogel, University of California, Berkeley.

Recipient: Bartholomew H. Sparrow, University of Texas at Austin.

Paper: "Raising Taxes and Going into Debt: A Resource Dependence Model of U.S. Public Finance in the 1940's.'”

Citation: The seventeen outstanding papers recommended to our committee's attention make up a pleasantly variegated bouquet, reflecting the broadened range of substantive concerns, and concomitant theoretical and methodological approaches, which characterizes the discipline today. Among them, Sparrow's paper is itself a vigorous hybrid, using organization theory to elucidate a major historical turning point in the relationship between state and society in America.

In thus combining theory and history, Sparrow joins the small band of innovators who have in recent years quietly revolutionized our understanding of American politics, and simultaneously liberated its study from the deadening grip of provincialism. In their desperate determination to achieve recognition as a useful scientific profession, an earlier generation of political scientists deliberately eschewed historical analysis, thereby depriving themselves and those who followed of one of the most effective intellectual tools available to the social sciences, and foregoing the possibility of challenging the complacency of conventional historians. But the eruption of a crisis in the relationships between state and society dramatically demonstrated the limitations of diachrony: to the extent that pluralist equilibrium prevailed as the major feature of American politics, it constituted but one moment, contingent on conditions that had differed earlier and would inevitably do so again.

Because of the circumstances that occasioned it, the emergence of the "historical persuasion" in the last two decades entailed more than a revival of interest in the past, but a theoretical concern with structural change, discontinuities and conflict. Ironically, its adherents were drawn back once again to the historical sociologists, or sociological historians, of the late nineteenth or early twentieth century, but now retrieved ideas that "modernization" had overlooked. One major theme is the perennial role of war in state-formation, the linkages between this and public finance, and the concomitant relationships between state and society more generally. Another theme is the emergence of a world economy, which has prompted an examination of its impact on what were hitherto considered "domestic" processes. Together, these themes have imparted a decidedly externalist cast to the various segments of macro-analytic political science.

The public was hardly unaware that in the middle of the third of the twentieth century, America began experiencing "big government." One result of the return of political scientists to history is that this major transformation now constitutes a legitimate object of scholarly analysis, which affords good possibilities of professional employment, and therefore is more likely to foster the commitment of talented young scholars.

The present work is richly suggestive. By focusing on public finance as a sphere that is not only intrinsically of the utmost importance, but in which the process of governmental transformation can be quite precisely chartered, Sparrow takes us well beyond the point where the "structuralist" pioneers brought us. The present work begins to elucidate more precisely how the transformation took place by identifying the mechanisms of institutional change during a crisis period, and in particular the respective contributions of different key actors-the president or Congress-to the vital policy domain indicated. Some of his most interesting observations arise from the analysis of the "terms of exchange" between government and social actors, and particularly the manner in which investors achieved much better bargains than taxpayers. Sparrow then goes on to suggest that America's changed role in the world at large explains why, in contrast with most previous phases of state expansion, changes in governmental institutions by and large persisted in the postwar period.

Albeit dealing with the specifics of one period and one sphere of policy, the paper also provides the makings of a broader interpretation of the course of American political development in the twentieth century as a whole. Sparrow concludes that, contrary to those who argue that "big government" was imposed from above, by way of "ideology" and bureaucratic self-interest, it arose by way of exchange: "The jointness of financial policymaking both limits the scope of governmental authority and implicates nominally private actors in the expansion of the federal government. The private became public and the public included the private. Both built the state."

\section{Heinz Eulau Award (\$500)}

For the best article published in The American Political Science Review during 1990.

Award Committee: David Laitin, University of Chicago, chair; Kathie S. Golden, University of Colorado, Colorado Springs; Jack Nagel, University of Pennsylvania; Martin Shefter, Cornell University.

Recipient: Kenneth N. Waltz, University of California, Berkeley.

Article: "Nuclear Myths and Political Realities."

Citation: The selection committee praised Professor Waltz's article for three outstanding characteristics. First, Waltz has focused his scholarly attention on an issue of paramount political importance-that of the relationship between nuclear technology and the likelihood of Great Power war, a dominant concern in Professor Waltz's distinguished career. In his earlier work, he emphasized the role of the structure of the international system, and argued that bipolarity was favorable to 
peace. In this paper, Waltz turns his attention to the specific qualities of military technology as his explanatory variable. While he does not in this paper compare the explanatory power of the structural and technological arguments, his continued focus on such a fundamental question is meritorious in itself.

Second, Waltz's fresh and counterintuitive argument, namely that our "happy condition" of peace has been cheaply procured through our investment in nuclear weapons, is made with great analytic rigor. Waltz's criticisms of those who would cheer for nuclear disarmament, of those who would build impregnable defenses, and of those who would build ever larger nuclear stockpiles are devastating and cogent.

Third, committee members were delighted that Waltz, abjuring jargon, writes brilliantly, and with wit. "Nuclear weapons," he argues "are small and light; they are easy to move, easy to hide, and easy to deliver in a variety of ways." Technical evidence to support these claims is absent: the stark reality of why it is wrong that "nuclear weapons have been given a bad name" comes through with shocking clarity.

\section{BOOK AWARDS}

\section{Ralph J. Bunche Award ( $\$ 500)$}

For the best scholarly work in political science published in 1990 which explores the phenomenon of ethnic and cultural pluralism.

Award Committee: Gwendolyn Mink, University of California, Santa Cruz, chair; David Garrow, City University of New York; Lorenzo Morris, Howard University.

Recipient: Frank R. Parker, Lawyers' Committee for Civil Rights Under Law.

Book: Black Votes Count, published by the University of North Carolina Press.

Citation: In Black Votes Count, Frank Parker illuminates the problem of political equality for African-Americans. He exposes the gap between voting rights and actual political representation in a study that brilliantly interweaves several themes: the significance of race, the stubbornness of local majorities, the role of federal litigation in the struggle by minorities for meaningful rights, and the political emergence of African-Americans in Mississippi. Parker's important account of one state's efforts to disfranchise Black people even while conceding their right to cast a ballot, and of civil rights litigation to tie rights to representation, contributes mightily to ongoing debates about equality law and the democratic process.
Gladys M. Kammerer Award (\$1,000)

For the best political science publication in 1990 in the field of U.S. national policy.

Award Committee: Alan Stone, University of Houston, chair; James S. Fleming, Rochester Institute of Technology; Jeanne T. Meadows, Spelman College.

Recipient: James A. Morone, Brown University.

Book: The Democratic Wish, published by Basic Books.

Citation: The Committee is pleased to choose James Morone's The Democratic Wish as the recipient of the 1991 Gladys M. Kammerer Award. During an era in which increasing specialization has come to characterize the study of public policy, Morone has crafted a tour de force. He has integrated American political thought and history with an understanding of contemporary public policy. Morone has forcefully argued that Americans have been subject to the destructive myth that political power can be removed from the state and placed directly in the hands of the people. While government has grown dramatically in both size and the scope of goals since the Founding, the underlying myth has led to the creation of institutional structures that have been unable to cope effectively with the problems they were intended to address. According to Morone the irony is that, in the name of democracy, the American state has been an ineffective one in policy area after policy area.

In the course of advancing his fundamental thesis, Morone has impressed the Committee with his breadth as well as his depth. He has done a remarkable job of reconstructing and interpreting the politics of class, race and medicine and applying them to appropriate policy areas. Individually, each of the areas he has covered is very complicated. Yet The Democratic Wish provides a convincing mastery of each area covered, while at the same time reinforcing the central thesis.

In summary, Morone has written an excellent and provocative book that clearly deserves the award bestowed on it.

\section{Benjamin E. Lippincott Award $(\$ 1,500)$}

For a work of exceptional quality by a living political theorist that is still considered significant after a time span of at least 15 years since the original publication; awarded biannually.

Award Committee: Arlene Saxonhouse, University of Michigan, chair; Amy Gutmann, Princeton University; Samuel P. Huntington, Harvard University.
Recipient: Michael Walzer, Institute for Advanced Study.

Book: The Revolution of the Saints: $A$ Study in the Origins of Radical Politics, published by Harvard University Press in 1965.

Citation: The Puritan saint, driven by insecurities about the world that is and a vision of the world that can be, becomes the prototype of the radical reformer in Michael Walzer's classic work, The Revolution of the Saints. In this pathbreaking, post-Weberian work on Protestantism, Walzer takes the ideology of the Puritans beyond its economics to its theological foundations and its political role, finding therein the origins of radicalism. The saint, active rather than passive, responsible rather than accepting, is committed to the political transformation of society. Vividly Walzer reveals the politicizing of religion, not by external manipulation, but by the force of its own ideology. Whereas the self-disciplined Calvinist saint was once considered an historical anomaly, Walzer's analysis shows him to be a prototypical agent of social and political reconstruction in the modern world. Seeking both social and selfcontrol, the Puritans are the first of several modern social movements whose religious zeal ushers in a new illiberal order, characterized by strict social control and repression, but perhaps laying the foundation for the liberal order that is to follow.

Historically detailed and theoretically complex, Walzer's account of the Puritan revolution is a model of how political theory can itself transform established understandings of history, religion, and politics. The analysis, startling at the time of publication in its rejection of the conventional readings of seventeenth century England and the Protestant Reformation, continues to inform analyses of political movements throughout modern history and around the world. In an age when religious fundamentalism often appears to be a regressive force, Walzer's work reminds us of religion's radical as well as repressive power. Though the arena of our interest may shift from Puritan England to Jacobin France to Bolshevik Russia, as in Walzer's book, or to the Iran of the Ayatollah or the liberation theologists of Latin America, we are indebted to The Revolution of the Saints for the theoretical capacity to understand the revolutionary drive for reform in the modern world.

\section{Victoria Schuck Award (\$500)}

For the best book published in 1990 on women and politics. 
Award Committee: Isaac Kramnick, Cornell University; Jo Freeman, Brooklyn, New York; Sonia Kruks, Oberlin College.

Recipients: Jane Sherron De Hart and Donald G. Mathews, University of North Carolina.

Book: Sex, Gender and the Politics of $E R A$, published by Oxford University Press.

Citation: In a richly nuanced study of the fate of the ERA amendment in the course of North Carolina ratification campaigns in 1973, 1975, and 1977, Professors Matthews and De Hart have captured the epic quality of a central moment in the modern story of women and politics. They go beyond mere narrative and electoral analysis to a provocative account of the way the battle over the ERA became an issue of gender politics. Whether it is their description of the paradoxical sharing on both sides of skeptical attitudes toward men and masculinity, or their emphasis on differing attitudes to traditional cultural roles, the authors have provided a deeply insightful look at the politics of gender in contemporary America.

Recipient: Iris M. Young, University of Pittsburgh.

Book: Justice and the Politics of Difference, published by Princeton University Press.

Citation: Iris Young's book emerges out of well over a decade of immersion in feminist theory and politics. In it, she develops an important critique of Rawlsian and neo-Rawlsian theories of justice. She argues that what she calls 'the distributive paradigm'-that is, the conception of justice as an equitable distribution of material, social and even political goods-is not adequate to the task of conceptualizing justice for women and minorities. Justice, she argues, is inseparable from empowerment, from ending forms of structural domination. Hence it is also inseparable from the political, from the development of participatory politics and institutions in particular. In addition, she argues, the participatory political institutions of a just society would have to respect the irreducibility of group differences, rather than trying to mold all its members to a single ideal of citizenship. Young's book is wide-ranging and multi-faceted, while also closely and carefully argued. It is a book with which feminists, feminist theorists and all others concerned with issues of justice, democracy and participation will have to reckon with for many years to come.
Woodrow Wilson Foundation Award $(\$ 5,000)$

For the best book published in the U.S. during 1990 on government, politics or international affairs (supported by the Woodrow Wilson Foundation).

Award Committee: Martin Schain, New York University, chair; Elinor Ostrom, Indiana University; Adolph Reed, Jr., Yale University.

Recipient: Charles E. Lindblom, Yale University.

Book: Inquiry and Change, published by Yale University Press and the Russell Sage Foundation.

Citation: We were asked to choose the best of 140 books that were submitted by publishers for this award, and we chose Charles Lindblom's book Inquiry and Change, published by Yale University Press and the Russell Sage Foundation. This is an award from the discipline to an author who analyzes our strengths and weaknesses in solving problems. He notes our accomplishments, but generally focuses on our pretenses. He questions whether social science inquiry can deal with, let alone solve, social problems. "Coming to grips with fundamentals always frustrates conclusiveness," he concludes. Nevertheless it is worth explaining how we probe, and how our probing may be improved. We agree. Congratulations.

\section{CAREER AWARDS}

\section{John Gaus Award $(\$ 1,500)$}

The John Gaus Distinguished Lecturer is to honor the recipient's lifetime of exemplary scholarship in the joint tradition of political science and public administration and, more generally, to recognize achievement and encourage scholarship in public administration.

Award Committee: John A. Rohr, Virginia Polytechnic Institute and State University, chair; Harry Bailey, Temple University; Jeane J. Kirkpatrick, American Enterprise Institute and Georgetown University.

Recipient: Norton E. Long, Professor Emeritus, University of Missouri, St. Louis.

Citation: The purpose of the John Gaus Award is to honor a scholar whose work, like that of Gaus himself, has relied upon the principles of political science to illuminate the problems of public administration. This is precisely what Norton Long has done during his long and distinguished career which is now in its seventh decade with, happily, no end in sight.
Public Administration is often described as the most practical area of political science. The first two decades of Norton Long's career, the 30's and the 40 's, presaged his remarkable contribution to the professional literature that joins theory and practice. He spent the 1930s as a student and instructor at Harvard University and the 1940s in wartime Washington first as assistant to the Administrator of the Office of Price Administration and later as assistant administrator of the National Housing Administration. The decades that followed brought forth a steady stream of scholarly books, reviews, and articles that have enriched our understanding of the intimate connection between political philosophy and administrative detail.

The titles of two of his best-known works, The Polity (1963) and The Unwelled City: Rebuilding the Urban Community (1972), capture nicely this theme of the rich interaction between the classical notion of polity and the distressingly contemporary problems of urban life.

Throughout his career, Norton Long has shown an abiding interest in interdisciplinary studies. As might be expected, his articles have graced the pages of the customary political science and public administration journals where most of us have come to know him. $\mathrm{He}$ has had a broader readership, however, than the members of our own profession. Looking just at the past two decades, one finds the articles of this prolific scholar in such diverse journals as the American Sociological Review, Urban Affairs Quarterly, the Journal of Community Psychology, Ethnicity, The Monthly Labor Review, and The Journal of the American Institute of Planners.

One of Norton Long's best known articles is "Power and Administration," which appeared originally in the Public Administrative Review in 1949 and has been reprinted many times. Here he delivers the coup de grace to the pompous pretensions of the defenders of the discredited orthodoxy of administration as science. The familiar opening paragraph of that famous article bears repeating here:

There is no more forlorn spectacle in the administrative world than an agency and a program possessed of statutory life, armed with executive orders, sustained in the courts, yet stricken with paralysis and deprived of power. An object of contempt to its enemies and of despair to its friends.

The author goes on to develop his theme that the "lifeblood of administration is power." The argument is so successful that the careful reader senses a certain uneasiness on the part of Norton 
Long at having empowered the administrator only to leave him in a normless political environment. Perhaps it is for this reason that shortly thereafter he revisits the question of administrative power in an extremely important article entitled "Bureaucracy and Constitutionalism" that appeared in APSR in 1952. Here Norton Long develops what I believe is the first serious and systematic effort to legitimate the power of the modern administrative state in terms of the American constitutional tradition-a theme that has had a profound influence on the subsequent development of normative theory in public administration.

I mention these two articles specifically because the first excels in telling us what administration is and the second in telling us what it should be. Together they encapsulate what this thoughtful man has been telling us so well over so many decades. Ad multos annos!

\section{Hubert H. Humphrey Award (\$500)}

Presented each year in recognition of notable public service by a political scientist.

Award Committee: Jewel L. Prestage, Prairie View A\&M University, chair; Xandra Kayden, Santa Monica, California; Morton J. Tenzer, University of Connecticut.

Recipients: Zbigniew Brzezinski, Center for Strategic and International Studies; C. Payne Lucas, Africare.

Citation: Zbigniew Brzezinski is a distinguished political scientist who has participated in government at the highest levels as National Security Advisor to the President of the United States. His commitment to scholarship is matched by his commitment to democracy and human rights, and he has served his profession and his nation well in the finest traditions represented by the Hubert Humphrey Award. His writings illuminate the processes of government, which is critical to the understanding of our democracy; and his work to shape a foreign policy that reflects the highest principles based on pragmatic realism is critical to the basis of a new international society. Dr. Brzezinski's vision of a foreign policy guided by moral principle has, in fact, become the cornerstone of the postcommunist world.

Currently holding the title of Counselor at the Center for Strategic and International Studies, and Professor of American Foreign Policy at the Paul Nitze School of Advanced International Studies, the Johns Hopkins University; he was on the faculty of Columbia University from 1960 to 1989; and of Harvard University from 1953 to 1960 . He holds a
Ph.D. from Harvard and attained a B.A. and M.A. from McGill University. Dr. Brzezinski served as National Security Advisor to President Jimmy Carter from 1977 to 1981 , and in 1981 was awarded the Presidential Medal of Freedom for his role in the normalization of U.S.-China relations and for his contributions to the human rights and national security policies of the United States.

He has also served as Director of the Trilateral Commission, and is a past member of the Board of Directors of Amnesty International, of the Council on Foreign Relations, and the Atlantic Council. He chaired the Hubert Humphrey Foreign Policy Task Force in 1968; and was the principal foreign policy advisor to Jimmy Carter in his 1976 campaign. In 1988, he was co-chair of the Bush National Security Advisory Task Force.

Dr. Brzezinski's books include The Grand Failure: the Birth and Death of Communism in the 20th Century; GamePlan: How to Conduct the U.S.-Soviet Contest; Power and Principle: The Memoirs of the National Security Advisor; The Fragile Blossom: Crisis and Chance in Japan; Between Two Ages: America's Role in the Technetronic Age; and The Soviet Bloc: Unity and Conflict.

Citation: C. Payne Lucas has had a long and distinguished career with public service agencies and organizations dedicated to improvement of the quality of life on the African continent. He has worked as a high ranking official in the Peace Corps and as Executive Director of Africare, a Washington-based private development organization dedicated to the improvement of the quality of life in rural Africa. Africare emphasizes marshalling the funds and technical assistance needed to help the African people help themselves. The organization's programs focus on health, food, water, refugee relief, and practical training for Black South Africa and Namibians studying at U.S. colleges and universities.

A native of North Carolina, Mr. Lucas received his undergraduate degree in History and Government from the University of Maryland, with Summa Cum Laude honors, and his M.A. in Government from American University. In 1962 he became Operations/Training Officer for the Peace Corps, Africa Region. Over the following nine year period he served as Associate Director and Deputy Director for Togo, ranking officer in Uganda and Kenya, Director for Niger, Deputy Director of the Peace Corps for Equal Employment Opportunity, Director of the Africa Region and Director of the Office of Returned Volunteers. Mr. Lucas was awarded the
Distinguished Federal Service Award in 1967 by President Lyndon B. Johnson. In addition, he received the Capitol Press Club's 1980 Humanitarian of the Year Award and the 1984 Presidential Hunger Award for Outstanding Achievement. The Phelps Stokes Fund presented him the 1986 Aggrey Medal for his work in establishing enduring friendships and cooperation between the United States and Africa. This was followed by the 1986 Officers of the Order of Distinguished Service Award from President Kenneth Kaunda of Zambia and the 1991 TransAfrica Freedom Award.

Currently he serves on the Boards of Directors of the Council on Foreign Relations, the Overseas Development Council, InterAction, International Science Agencies, the Environmental and Energy Study Institute, the Citizens' Network for Foreign Affairs, International Voluntary Services and the Population Crisis Committee. He co-authored (with Kevin Lowther) Keeping Kennedy's PromiseThe Peace Corps: Unmet Promise of the New Frontier.

Mr. Lucas, a political scientist who opted for a public service career, has exhibited a sustained commitment to the high standards of professionalism and humanitarianism reflected in the life and work of Hubert Humphrey and in the Association's decision to establish the Hubert Humphrey Award.

\section{Carey McWilliams Award (\$500)}

Presented each year to honor a major journalistic contribution to our understanding of politics.

$A$ ward Committee: Scarlett G. Graham, Vanderbilt University, chair; Glen Browder, U.S. House of Representatives; Donna Shalala, University of Wisconsin.

Recipient: Molly Ivins, Dallas TimesHerald.

Citation: The Carey McWilliams Award was established "to honor a major journalistic contribution to our understanding of politics." It is altogether right and proper that we should attend closely to the quality of political journalism in the nation. Because of the nature of our craft, political scientists are often far removed from the day-to-day street-level politics that most of the citizenry easily recognize as politics. In our correct insistence on achieving as much precision as possible in our ongoing conversation among ourselves, we rely on a vocabulary that seems further to remove us from our fellow citizens.

Political journalists go a long way toward bridging the gap between systematic examination of politics and the ongoing conversation about politics among the public. The best of them bring 
a trained and discerning eye to their examination of the nation's political life and an exceptional ability to communicate their observations to a segment of the community for whom politics is just one more part of life, and not an object of examination, study, and contemplation.

This year's recipient of the Carey McWilliams award easily qualifies as one of the best of them. Molly Ivins of the Dallas Times Herald was selected by a committee composed of Donna Shalala (University of Wisconsin), Glen Browder (distinguished member of the U.S. House of Representatives), and myself. In support of Molly as the committee's choice for this year's award, a committee member made this observation about her and her work:

"One of the most thoughtful and funny political writers in America, she is a journalist's journalist. If you asked journalists the best writers in American political journalism, Ivins would be on the short list."

That Molly was named Outstanding Alumna by Columbia University's School of Journalism in 1976 serves as evidence that she is held in high regard by her peers. Her brief biography as she has written it serves as evidence that she is both a thoughtful and funny political writer. Molly describes herself and her career as follows:

$$
\text { by Molly Ivins }
$$

Molly Ivins is a columnist for the Dallas Times Herald, where she writes about Texas politics and other bizarre happenings.

Ivins is from Houston, has a B.A. from Smith College, a master's in journalism from Columbia University and studied for a year at the Institute of Political Science in Paris. She began her career in journalism at the Complaint Department of the Houston Chronicle. She rapidly worked her way up to the position of sewer editor, from whence she wrote a number of gripping articles about street closings. She next went to work for the Minneapolis Tribune, first as a police reporter and later on a beat called Movements for Social Change. She covered militant blacks, angry Indians, radical students, uppity women and a motley assortment of other misfits and troublemakers.

In 1970, Ivins returned to Texas as co-editor of the Texas Observer, a sprightly, muck-raking publication devoted to coverage of Texas political and social events.
Her specialty was covering the Texas Legislature, which has given her an extremely strong stomach.

In 1976, Ivins joined The New

York Times as a political reporter, first at City Hall and then at the statehouse in Albany. In 1977, she was named Rocky Mountain

Bureau Chief, chiefly because there was no one else in the bureau. She covered nine mountain states by herself and was often tired.

She returned once more to Texas in 1982 , which may indicate a masochistic streak, and has had plenty to write about ever since.

Ivins' freelance work has appeared in Esquire, Atlantic, The Nation, Harper's, TV Guide and numerous other publications. She also does occasional commentary for National Public Radio and the McNeil/Lehrer program. She served for three years on the board of the National News Council, is active in Amnesty International's Journalism Network and the Reporters Committee for Freedom of the Press. She writes about press issues for the American Civil Liberties Union and several journalism reviews. She has received a number of journalism awards and in 1976 was named Outstanding Alumna by Columbia University's School of Journalism.

However, Ivins counts as her two greatest honors that the

Minneapolis police force named its mascot pig after her and that she was once banned from the campus of Texas A\&M.

On behalf of the American Political Science Association, this year's Committee is pleased to name Molly Ivins as the winner of the Carey McWilliams Award for distinguished political journalism.

\section{APSA Publications List}

\section{PERIODICALS}

The American Political Science Review. The leading quarterly journal of scholarly articles and book reviews in political science. Included in APSA membership. Back issues: $\$ 20$ per copy, add $\$ 1.50$ postage or $\$ 3$ overseas; $\$ 80$ per volume, add $\$ 5$ postage or $\$ 10$ overseas.

PS: Political Science \& Politics. Quarterly journal of Association news and lively articles of political analysis. $P S$ is the best single source of information on professional opportunities. Included in
APSA membership. Back issues: $\$ 10$ per copy, add $\$ 1.50$ postage or $\$ 3$ overseas; $\$ 20$ per volume, add $\$ 5$ postage or $\$ 10$ overseas (\$15 for the spring issue which contains the preliminary program, add $\$ 1.50$ postage or $\$ 3$ overseas).

The Political Science Teacher. Stimulating quarterly magazine on education, curriculum, and teaching. Distributed to U.S. individual members only. Fall 1990 issue was the last separate issue of The Teacher. As of March 1991 The Teacher was incorporated into PS. Back issues of The Teacher are available while supply lasts for $\$ 4$ each (includes postage).

this Constitution: A Bicentennial Chronicle. A special Fall 1991 issue devoted to the Bill of Rights will be available at $\$ 6$ per copy. Add \$1 postage each copy.

\section{DIRECTORIES}

APSA Membership Directory. Names, addresses, current position, institutional affiliation, highest degrees, and fields of specialization of APSA individual members. Index includes listings of women, Black, and Hispanic political scientists, a geographical listing of members, and a listing of members by fields of interest. 1991-93. \$30 members; $\$ 50$ nonmembers (+ $\$ 2.50$ postage). Triennial.

APSA Biographical Directory. Names, addresses, current position, institutional affiliation, highest degree, fields of specialization, and honors and publications of APSA individual members. Index includes listings of women, Black and Hispanic members, a geographical listing, and a listing of members by fields of interest. $\$ 25$, APSA members; $\$ 35$, nonmembers $(+\$ 2.50$ postage). 1988 .

Directory of Black Americans in Political Science. Lists over 400 Black American political scientists by name, address, phone, degrees, and fields of specialization. Indexed by field of academic specialization and research interests. $\$ 10$, APSA members; $\$ 15$, nonmembers (+\$2.50 postage). 2nd edition, 1988.

Directory of Undergraduate Political Science Faculty, 1990. Lists undergraduate departments offering political science with name, address, phone number, and names and specializations of faculty members. \$15, APSA members; \$20 nonmembers (+ \$2.50 postage). Triennial.

Annual APSA Directory of Department Chairpersons. Names and addresses of chairpersons in departments offering political science at four-year institutions. $\$ 20$ each (+ $\$ 2.50$ postage). Annual, November.

\section{INDEXES}

Cumulative Index to the American 